\title{
Cutinase and Other Lipolytic Esterases Protect Bean Leaves from Infection by Rhizoctonia solani
}

\author{
Diana M. Parker and Wolfram Köller \\ Department of Plant Pathology, Cornell University, New York State Agricultural Experiment Station, Geneva, \\ NY 14456, U.S.A. \\ Accepted 7 February 1998.
}

\begin{abstract}
The results describe a novel activity of fungal cutinase, the protection of bean leaves from disease. Development of web blight symptoms on bean leaves infected with $R$ hizoctonia solani (AG-1) was prevented in the presence of cutinase purified from Venturia inaequalis. Instead of disease, small areas of tissue necrosis became visible, and the tissue in which the pathogen was restricted displayed strong autofluorescence beneath the inoculation sites. Mechanical wounding of the leaf surface had no effect on disease development and the permeability of the cuticle was not increased by cutinase action, indicating that surface wounding was not the cause for this novel activity of cutinase. A comparative study involving cutinase and other serine hydrolases revealed that the disease prevention resided in the lipolytic esterase activity rather than the cutinase activity. The pattern of expression of four pathogenesis-related (PR) protein genes provided no evidence for the modulation of known resistance responses of bean leaves in response to cutinase action. The protective mechanism of the esterase activity remains unknown.
\end{abstract}

Additional keywords: carboxylesterase, lipase, Phaseolus vulgaris, proteinase K, Thanatephorus cucumeris.

The plant cuticle, composed of a hydroxyfatty acid polyester impregnated with waxes, constitutes a physical barrier against invading pathogens. Cutinases, cutin-hydrolyzing enzymes, have been associated with the ability of fungal pathogens to penetrate into their hosts (Kolattukudy 1985; Kolattukudy et al. 1995a, 1995b; Köller 1991; Köller et al. 1995). More recent research employing the disruption of several cutinase genes described in the past did not confirm involvement of respective cutinases in plant infection (Crowhurst et al. 1997; Köller et al. 1995; Stahl et al. 1994; Sweigard et al. 1992; van der Vlugt-Bergmans et al. 1997; van Kan et al. 1997; Yao and Köller 1995). However, the release of other cutinolytic esterases from germinating spores has been reported for several plant pathogens (Deising et al. 1992; Fan and Köller 1998; Francis et al. 1996; Köller et al. 1982; Nicholson and Kunoh 1995; Pascholati et al. 1993; Yao and Köller 1995), and their involvement in surface penetration (Köller et al. 1995; Köller and Yao 1996) or in the attachment of spores to host surfaces (Nicholson and Kunoh 1995) has been suggested.

Corresponding author: W. Köller; E-mail: wk11@ cornell.edu
In our previous studies on cutinase involvement in the tissue specificity of fungal pathogens, we had amended the surfaces of bean leaves challenged by the stem-specific pathogen Rhizoctonia solani Kühn (AG 2-2) (Thanatephorus cucumeris (A. B. Frank) Donk) with cutinase (Trail and Köller 1990). The presence of cutinase purified from the leaf-specific pathogen Venturia inaequalis enabled the stem-specific pathogen to invade bean leaves (Trail and Köller 1990). However, the macroscopic symptoms displayed were small areas of necrotic tissue rather than the water-soaked and rapidly expanding lesions typical for bean leaves infected by the closely related web blight fungus Rhizoctonia solani (AG-1) (Dillard 1987; Galindo et al. 1982; Muyolo et al. 1993; Schwartz 1991; Yang et al. 1990).

Necrotic tissue has been associated with the hypersensitive response (HR) of host plants to pathogen attack (Goodman and Novacky 1994). Such resistance responses are normally accompanied by the induction of pathogenesis-related (PR) proteins (Dixon et al. 1994; Hammond-Kosack and Jones 1996; Knogge 1996; Ryals et al. 1996). Elicitors of PR-protein expression include, among a variety of pathogen- and hostderived components (Boller 1995), fatty acids and fatty acid derivatives such as linolenic and jasmonic acid (Bergey et al. 1996; Creelman and Mullet 1995; Farmer 1994) and hydroxyfatty acids as monomer constituents of cutin (Schweizer et al. 1996a, 1996b). In addition, cutin monomers are known to be active as inducers of fungal cutinases (Kolattukudy et al. 1995a, 1995b; Li and Kolattukudy 1995, 1997; Woloshuk and Kolattukudy 1986).

Products of cutin hydrolysis could have been responsible for the necrotic lesions on bean leaves challenged with the stem-specific pathogen $R$. solani (AG2-2) in the presence of cutinase purified from V. inaequalis (Trail and Köller 1990). This study describes and explores the protective effect of cutinase and other serine esterases on the infection of bean leaves by $R$. solani (AG-1), the causal agent of web blight (Dillard 1987; Galindo et al. 1982; Muyolo et al. 1993; Schwartz 1991; Yang et al. 1990).

\section{RESULTS}

Effect of cutinase on the infection of bean leaves by Rhizoctonia solani.

Drop inoculation of excised bean leaves with mycelial suspensions of the web blight fungus $R$. solani (AG-1) generated grayish brown, circular lesions with a halo of water-soaked 
tissue (Fig. 1A and B). These symptoms were typical for web blight (Schwartz 1991). Treatment of leaves with droplets containing $10 \mu \mathrm{g} \mathrm{ml}^{-1}$ cutinase purified from $V$. inaequalis (Köller and Parker 1989) produced no macroscopic changes of the underlying tissue (Fig. 1A and C). In contrast, inoculation droplets of $R$. solani (AG-1) amended with the same amount of cutinase led to small areas of necrotic tissue (Fig. 1A and D), which closely resembled the symptoms observed after inoculations of bean leaves with the stem-specific $R$. solani (AG 2-2) amended with the same cutinase (Trail and Köller 1990). Identical results were obtained with cutinase purified from $F$. solani f. sp. pisi (data not shown).

The serine esterase inhibitor $O$-methyl- $O$-butyl- $O$-(3,5,6trichloro-2-pyridyl) phosphate has been described previously as a potent inhibitor of the $V$. inaequalis cutinase (Köller et al. 1991). Inclusion of the inhibitor at fully inhibitory doses in excised leaf assays abolished the cutinase activity of protecting bean leaves from web blight infection (Table 1). The result indicated that the protective activity of cutinase resided in the enzymatic activity rather than in protein-related features of the enzyme.

The formation of necrotic tissue was dependent on the cutinase dose, resulting in complete protection at a concentration of $10 \mu \mathrm{g} \mathrm{ml}^{-1}$ (Table 2). All subsequent tests were performed at this concentration. Generation of necrotic tissue at $10 \mu \mathrm{g} \mathrm{ml}^{-1}$ and $50 \mu \mathrm{g} \mathrm{ml}^{-1}$ cutinase (Table 2) required the presence of the detergent Tween 20 at a minimal concentration of $0.1 \%$. At this concentration, lesion development in the absence of cutinase was delayed for approximately $12 \mathrm{~h}$ when compared with mycelial inoculum suspended in water. Subsequent to this initial lag phase, the dynamics of rapid lesion development were not different.

In bean hypocotyls infected with $R$. solani (AG-1), autofluorescence due to pathogen-induced phenylpropanoid synthesis had been reported for host cells in the vicinity of $R$. solani (AG-1) hyphae expanding in diseased stem tissue (Stockwell and Hanchey 1987). Diffuse autofluorescence was also apparent in the entire area of web blight symptoms on bean leaves after infection with the web blight fungus $R$. solani (AG-1), with fluorescence most pronounced at the perimeter of expanding lesions (Fig. 1E). Cutinase alone caused no autofluorescence (Fig. 1F), whereas the pathogen amended with cutinase induced strong autofluorescence in areas restricted to tissue beneath inoculation sites (Fig. 1G).

In numerous repetitions of amendment experiments, disease never developed from the necrotic tissue during a 48-h time course. To investigate the durability of the cutinase effect and to assess the impact of leaf excision on disease development, similar tests were performed with intact plants. After 6 days, bean plants inoculated with $R$. solani (AG-1) showed severe symptoms and had collapsed, while plants inoculated with cutinase-amended inoculum remained free of symptoms. Amended $R$. solani (AG-1) developed superficial mycelia at the inoculation site but did not cause any disease symptoms (Fig. 1J).

\section{Effect of cutinase on leaf surface properties.}

Cuticular membranes impermeable to polar compounds such as glucose and proteins were shown to become readily permeable and porous after treatment with cutinase derived from F. solani (Baker et al. 1982). Therefore, the necrosis- inducing properties of cutinase described above could relate to either a wound response known to induce plant defense reactions (Ryan 1984; Lawton and Lamb 1987; Brederode et al. 1991; Mehta et al. 1991) or to an increased permeability of the cuticle facilitating a more rapid diffusion of pathogen-derived elicitors into the host, thus allowing accelerated defense reactions. Both aspects were investigated.

Surfaces of bean leaves were wounded by gentle abrasion with Carborundum (Stockwell and Hanchey 1985) prior to inoculation with the pathogen. Web blight symptoms developed freely on these wounded surfaces (Fig. 1H) regardless of strong autofluorescence beneath noninoculated wound areas after $48 \mathrm{~h}$ (Fig. 1I). This autofluorescence, which was not observed in response to cutinase (Fig. 1F), indicated rapid induction of wound-healing reactions (Smith et al. 1994) with no apparent effect on web blight development (Fig. 1H).

Increased permeability of cuticles caused by cutinase was investigated by treating delineated areas of bean leaf surfaces for $24 \mathrm{~h}$ with either a solution of $0.1 \%$ Tween 20 alone or the detergent containing cutinase. As a control, delineated leaf surfaces were gently wounded with Carborundum to mechanically permeabilize the cuticle. Penetration of polar compounds into the leaf was measured by exposing respective surfaces to a mixture of radioactive amino acids for $2 \mathrm{~h}$. Uptake of amino acids into wounded tissue was much higher $(P<0.001)$ than for either nonwounded surface (Table 3). Although cutinase treatment allowed a slightly higher level of amino acids to be retained by the leaf tissue (Table 3), the difference was not significant $(P=0.3)$. Differences observed for the uptake of amino acids were not caused by a physical adsorption to leaf surfaces, because retention of amino acids after brief contact with the leaf surface was very small in comparison (Table 3 ).

\section{Activities of other lipolytic esterases.}

Fungal cutinases are typical serine esterases (Köller and Kolattukudy 1982; Martinez et al. 1992). Recent research has shown that, in addition to its cutinolytic activity, cutinase derived from $F$. solani is also active as a lipase (Longhi et al. 1997; Mannesse et al. 1995; Martinez et al. 1992, 1994; Ohnishi et al. 1995). Likewise, several lipases derived from Pseudomonas spp. were shown to exhibit cutinolytic activity (Gérard et al. 1993). In addition to their natural substrates, both cutinases and Pseudomonas lipases hydrolyze soluble model esters such as $p$-nitrophenyl butyrate (PNB) (Gilbert et al. 1991; Kolattukudy 1985; Köller 1991). Nonspecific esters are also accepted as substrates by carboxylesterases (Krisch 1971) and some serine proteases such as proteinase K (Whittaker et al. 1994).

To evaluate the proteinaceous and enzymatic requirements for the novel plant protective activity of cutinase, the cutinase from $V$. inaequalis, the cutinolytically active lipases $\mathrm{AK}$ and PS 30 from Pseudomonas spp. (Gérard et al. 1993), carboxylesterase from pork liver, and proteinase $\mathrm{K}$ from Tritirachium album were used in a comparative study. As summarized in Table 4, the $V$. inaequalis cutinase displayed a much higher cutinase- and PNBase-specific activity than either lipase. The ratios of cutinase and PNBase activities demonstrated, furthermore, that the cutinase relative to esterase activities were at least 13 times higher for the $V$. inaequalis cutinase than for the lipases (Table 4), confirming the expected preference for cutin as the enzyme substrate. 


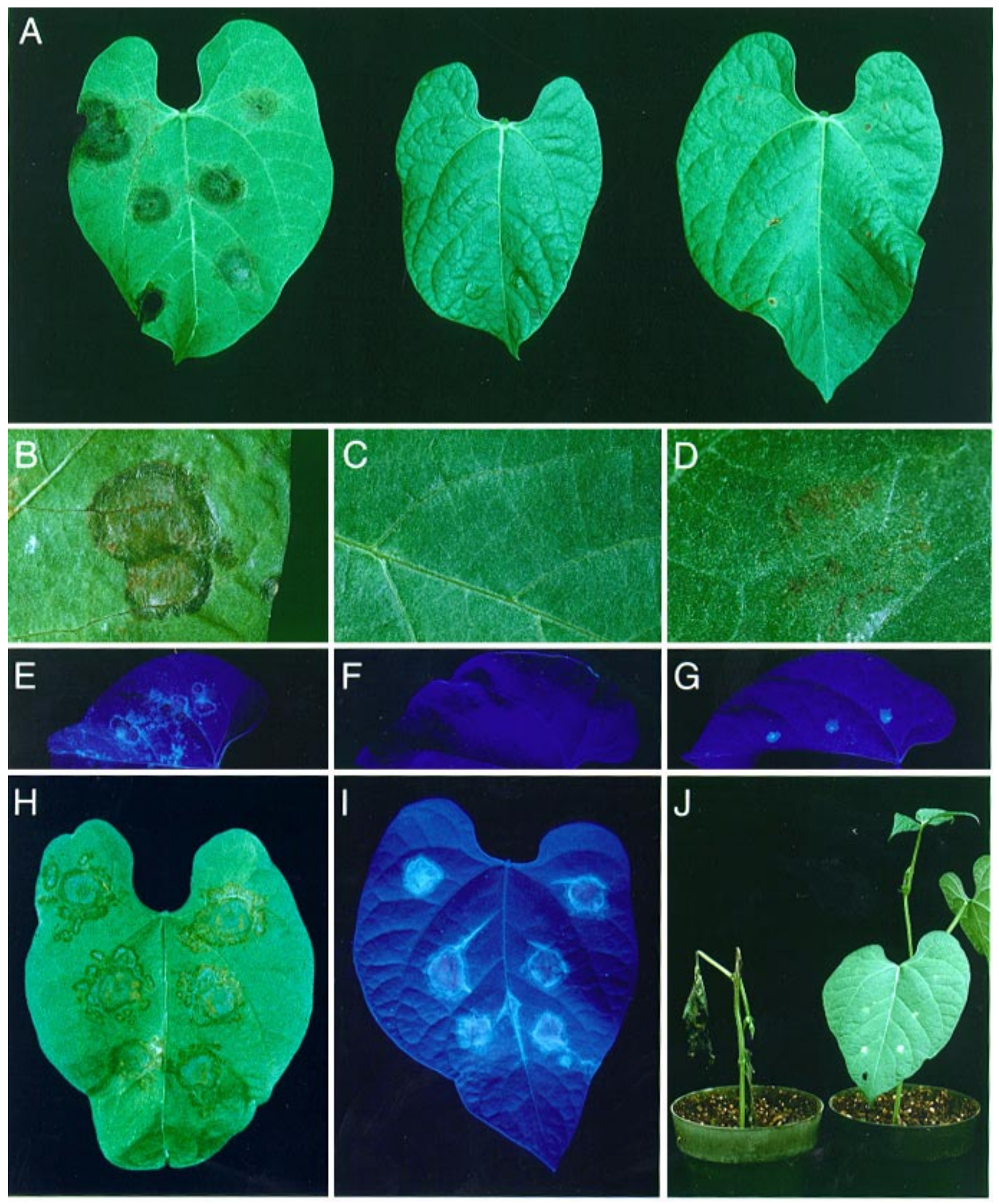

Fig. 1. Pathogenicity of Rhizoctonia solani (AG-1) on bean leaves. A, Excised bean leaf assay with typical water-soaked lesions (left), no apparent tissue response from cutinase alone (center), and necrotic tissue formed in the cutinase amended treatment (right). B, Enlargement of a typical water-soaked lesion. C, Enlargement of a site treated with cutinase only. D, Enlargement of necrotic tissue. E, Autofluorescence of a typical water-soaked lesion. F, Autofluorescence of a cutinase-treated site. G, Autofluorescence at the site of necrotic tissue formation. H, Bean leaf mechanicaly wounded with Carborundum and showing typical water-soaked lesions from infection by $R$. solani. I, Autofluorescence of a bean leaf mechanically wounded with Carborundum. J, Bean plants inoculated with $R$. solani (left) or $R$. solani amended with cutinase (right). Photo was taken 6 days after inoculation. 
Each of the five enzymes was tested at $10 \mu \mathrm{g} \mathrm{ml}^{-1}$ for its effect on web blight development (Table 2). Disease was prevented only in the cutinase-amended sample, indicating that the effect was not proteinaceous in nature (Table 5). In contrast, when each enzyme was applied at a PNBase activity of $0.175 \mu \mathrm{kat} \mathrm{ml}^{-1}$, equivalent to the optimal cutinase concentration (Table 4), disease was controlled in the presence of all enzymes except proteinase K (Table 5). At this PNBase level, cutinolytic activities were $64.7 \mathrm{cu} \mathrm{ml}^{-1}$ for cutinase and $<0.15$ $\mathrm{cu} \mathrm{m} \mathrm{m}^{-1}$ for all other enzymes tested (Table 4). As shown in Table 1, the cutinase concentration required for a diseasepreventing effect was $>1 \mu \mathrm{g} \mathrm{ml}^{-1}$, reflecting a cutinase activity of $>6.5 \mathrm{cu} \mathrm{ml} \mathrm{m}^{-1}$. The result indicated that the diseasepreventing properties of the esterases were dependent on their esterase rather than cutinase activities and that the esterase activity of the serine protease was not sufficient to halt web blight development (Table 5).

\section{Induction of $P R$ protein genes.}

To investigate the induction of PR proteins previously described for bean, Northern (RNA) analysis of leaf tissue beneath treated areas was used to determine the mRNA accumulation levels for phenylalanine ammonia lyase (PAL) and chalcone isomerase (CHI), two key enzymes of phenylpropanoid synthesis (Dixon and Paiva 1995; Mahé et al. 1992, 1993; Meier et al. 1993), chitinase (CHT) as an example of a potentially antifungal enzyme (Hedrick et al. 1988; Lange et al. 1996; Mahé et al. 1992, 1993; Meier et al. 1993) and malic enzyme (Walter et al. 1988, 1994; Schaaf et al. 1995) suggested to contribute to NADPH-replenishing and oxidative reactions important in plant defense.

Analysis was performed 6 and $36 \mathrm{~h}$ after exposure of leaves to cutinase alone, to the pathogen, or to the pathogen amended with cutinase. By $36 \mathrm{~h}$, leaves inoculated with the pathogen alone started to develop small, water-soaked lesions. In all other treatments, no visible symptoms were displayed. With

Table 1. Effect of cutinase inhibition on lesion development by Rhizoctonia solani (AG-1) on excised bean leaves

\begin{tabular}{|c|c|}
\hline Inhibitor concentration $^{\mathrm{a}}(\mu \mathrm{g} / \mathrm{ml})$ & ${\text { Lesion } \operatorname{size}^{\mathrm{b}}(\mathrm{mm})}$ \\
\hline Control $^{c}$ & $10.6 \pm 2.0$ \\
\hline 0 & $0.0^{\mathrm{d}}$ \\
\hline 4 & $10.0 \pm 2.3$ \\
\hline 40 & $9.6 \pm 3.1$ \\
\hline
\end{tabular}

${ }^{a} O$-methyl- $O$-butyl- $O$-(3,5,6-trichloro-2-pyridyl) phosphate.

${ }^{\mathrm{b}}$ Mean of 36 inoculation sites in the presence of $0.1 \%$ Tween 20 .

${ }^{\mathrm{c}}$ In the absence of cutinase.

${ }^{\mathrm{d}}$ Necrotic tissue.

Table 2. Effect of cutinase concentration on lesion development by Rhizoctonia solani (AG-1) on excised bean leaves

\begin{tabular}{|c|c|}
\hline Cutinase concentration $^{\mathrm{a}}(\mu \mathrm{g} / \mathrm{ml})$ & Lesion size $^{\mathrm{b}}(\mathrm{mm})$ \\
\hline 0 & $7.7+1.3$ \\
\hline 1 & $7.6+0.6$ \\
\hline 5 & $1.0^{\mathrm{c}}$ \\
\hline 10 & $0.0^{\mathrm{d}}$ \\
\hline 50 & $0.0^{\mathrm{d}}$ \\
\hline
\end{tabular}

${ }^{\mathrm{a}}$ In the presence of $0.1 \%$ Tween 20.

${ }^{\mathrm{b}}$ Mean of 20 inoculation sites.

${ }^{\mathrm{c}}$ Nascent lesions.

${ }^{\mathrm{d}}$ Necrotic tissue. the exception of CHT, the level of PR-protein gene expression in nontreated leaves was very low and mostly below detection limits (Fig. 2). The elevated level of CHT mRNA was caused by the excision of leaves, as revealed by an analysis of leaf tissue extracted immediately after excision (data not shown), as previously reported (Hedrick et al. 1988). No hybridization signals were detected with RNA isolated from the pathogen $R$. solani (data not shown).

Exposure of leaves to the detergent solution had minimal effect on expression of the genes examined (Fig. 2). Furthermore, addition of cutinase to the detergent solution did not affect gene expression, indicating that cutinase action was distinctly different from the inductive properties of general elicitors such as fungal cell wall components or chemicals relating to salicylic acid (Dann et al. 1996; Edwards et al. 1985; Mehdy and Lamb 1987; Walter et al. 1988; Hedrick et al. 1988). Gene expression, which was not elevated in the presence of cutinase, reached high levels in the presence of the pathogen $6 \mathrm{~h}$ after inoculation (Fig. 2). Levels of PR-protein mRNA remained high only in leaf tissue fully invaded by the pathogen, whereas levels had declined after $36 \mathrm{~h}$ to almost background when cutinase was present at the inoculation sites (Fig. 2). The result indicated that inductive conditions leading to cutinase-mediated protection and the formation of necrotic tissue (Fig. 1) no longer existed during this later stage of protective events.

\section{DISCUSSION}

In this study, we describe a novel activity of cutinase, the protection of plants from disease development. Thus far, functions of cutinases produced by plant-pathogenic fungi have been associated with cuticle penetration of pathogenic fungi, adhesion of spores to host surfaces, and crucial functions in the saprophytic utilization of cutin as carbon source (Kolattukudy 1985, 1992; Köller 1991; Köller et al. 1995; Köller and Yao 1996; Nicholson and Kunoh 1995; Schäfer 1993, 1994). More recently, cutin monomers as products of

Table 3. The effect of cuticle treatments on the uptake of amino acids

\begin{tabular}{|c|c|}
\hline Leaf treatment & Mean activity (bq) \\
\hline Residual $^{\mathrm{a}}$ & 8.6 \\
\hline Wounded & 2,796 \\
\hline Detergent $\mathrm{t}^{\mathrm{b}}$ & 323 \\
\hline Cutinase + detergent $^{\mathrm{c}}$ & 561 \\
\hline
\end{tabular}

${ }^{a}$ Physical surface adsorption.

b $0.1 \%$ Tween 20 .

c $10 \mu \mathrm{g}$ of cutinase per $\mathrm{ml}$ and $0.1 \%$ Tween 20 .

Table 4. Cutinase and esterase activities of serine hydrolases

\begin{tabular}{|c|c|c|c|}
\hline \multirow[b]{2}{*}{ Enzyme } & \multicolumn{2}{|c|}{ Activity } & \multirow[b]{2}{*}{ Cutin/esterase } \\
\hline & $\begin{array}{c}\text { Cutinase }^{\mathrm{a}} \\
\text { (cu/mg) }\end{array}$ & $\begin{array}{c}\text { Esterase }^{b} \\
(\mu \mathrm{kat} / \mathrm{mg})\end{array}$ & \\
\hline Cutinase & $6,466.0$ & 17.5 & 369.5 \\
\hline Lipase PS 30 & 14.4 & 1.2 & 12.0 \\
\hline Lipase AK & 5.5 & 0.2 & 27.5 \\
\hline Esterase & $\mathrm{ND}^{\mathrm{c}}$ & 2.6 & $<4.8$ \\
\hline Proteinase $\mathrm{K}$ & ND & 0.06 & $<4.8$ \\
\hline
\end{tabular}

${ }^{\mathrm{a}} \mathrm{cu}$ (cutinase units) $=\mathrm{Bq}$ released from labeled cutin per minute.

b Tested with $p$-nitrophenyl butyrate as substrate (PNBase).

c Not detected: beelow detection limits of the cutinase assay. 
cutinase action have been suggested to serve as signal molecules for the induction of resistance responses in barley, rice, and potato (Schweizer et al. 1995, 1996a, 1996b). Here, we have demonstrated that amending inoculum with cutinase derived from $V$. inaequalis prevented the development of web blight symptoms on bean leaves. Instead of typical disease symptoms, small areas of necrotic tissue developed as a durable response to infection.

It has been shown that the cutinase of $F$. solani also has lipase activity (Longhi et al. 1997; Martinez 1992, 1994; Mannesse et al. 1995). This additional lipase character of the cutinase was substantiated by the recent characterization of a lipase from the nonpathogenic fungus Aspergillus oryzae with close homologies to the Fusarium solani enzyme (Ohnishi et al. 1995), a finding consistent with the description of the $F$.

Table 5. Lesion development by Rhizoctonia solani (AG-1) on excised bean leaves resulting from inoculum amendment with enzymes at a constant protein concentration or a constant esterase activity

\begin{tabular}{lcc}
\hline & \multicolumn{2}{c}{ Lesion size $^{\mathbf{a}}(\mathbf{m m})$} \\
\cline { 2 - 3 } Enzyme & Protein $^{\mathbf{b}}$ & Esterase $^{\mathbf{c}}$ \\
\hline None & $13.8+1.4$ & $9.4+4.0$ \\
Cutinase & 0.0 & $0.0^{\mathrm{d}}$ \\
Lipase PS 30 & $11.2+5.4$ & $0.0^{\mathrm{d}}$ \\
Lipase AK & $12.4+2.3$ & $0.0^{\mathrm{d}}$ \\
Esterase & $11.6+3.3$ & $0.0^{\mathrm{d}}$ \\
Proteinase K & $12.8+2.4$ & $15.3+2.5$ \\
\hline
\end{tabular}

a Mean of 36 inoculation sites.

b $10 \mu \mathrm{g} / \mathrm{ml}$.

c $0.175 \mu \mathrm{kat} / \mathrm{ml}$ PNBase.

${ }^{\mathrm{d}}$ Necrotic tissue.

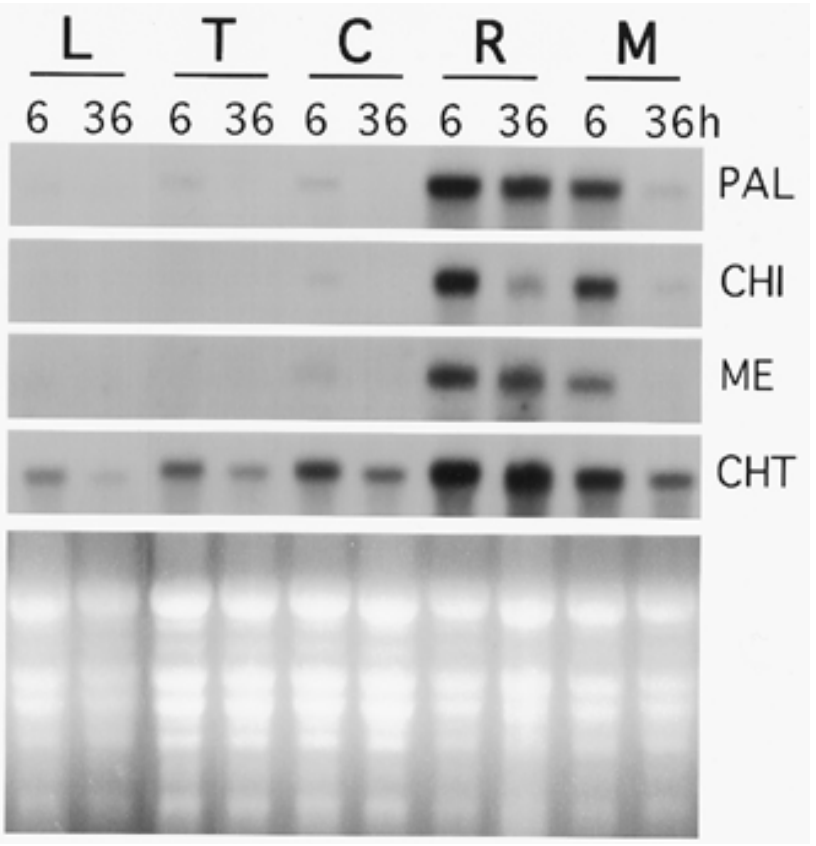

Fig. 2. A Northern (RNA) blot containing total RNA extracted at 6 and $36 \mathrm{~h}$ from nontreated leaves (L) or leaves treated with $0.1 \%$ Tween 20 (T), cutinase $(10 \mu \mathrm{g} / \mathrm{ml})$ in $0.1 \%$ Tween 20 (C), Rhizoctonia solani (AG1 ) in $0.1 \%$ Tween $20(\mathrm{R})$, or $R$. solani (AG-1) amended with cutinase (10 $\mu \mathrm{g} / \mathrm{ml})$ in $0.1 \%$ Tween $20(\mathrm{M})$ and hybridized with the pathogenesisrelated protein cDNAs of phenylalanine ammonia lyase (PAL), chalcone isomerase (CHI), malic enzyme (ME), and chitinase (CHT). The ethidium bromide-stained gel demonstrates equal loading of samples. solani cutinase as an evolutionary link between lipases and esterases (Martinez et al. 1992). The cutinase employed in this study was purified from $V$. inaequalis (Köller and Parker 1989) and shares characteristic features with the $F$. solani cutinase, which was also active in preventing symptom development. The enzyme is produced under saprophytic conditions; it is a serine esterase; it hydrolyzes cutin to monomers; and it is induced by cutin monomers (Köller and Parker 1989; Köller et al. 1991). The major difference relative to the $F$. solani enzyme is a different $\mathrm{pH}$ optimum of cutin hydrolysis and a higher degree of hydrophobicity (Köller and Parker 1989).

Inclusion of the active serine-directed inhibitor $O$-methyl$O$-butyl- $O$-(3,5,6-trichloro-2-pyridyl) phosphate in excised leaf assays revealed that the protective property of cutinase resided in the enzymatic activity rather than in any feature relating to the protein. The disease-preventing property of the $V$. inaequalis cutinase was dose dependent within the narrow range of 5 to $10 \mu \mathrm{g} \mathrm{ml}^{-1}$ and, within this range of activity, was dependent on the presence of a detergent. Although not fully understood at present, the detergent effect might relate to the high hydrophobicity of cutinase, which is not readily soluble in water as a purified enzyme (Köller and Parker 1989).

A comparative study aimed at the characterization of cutinase properties responsible for the disease-preventing activity included two microbial lipases reported to also exhibit cutinase activity (Gérard et al. 1993), carboxylesterase as a nonspecific esterase with a broad substrate specificity toward a large variety of esters (Krisch 1971), and proteinase K, a subtilisin-like serine protease (Siezen and Leunissen 1997) with residual nonspecific esterase activity (Whittaker et al. 1994). The results combined demonstrated that (i) the diseaseprotecting activity of cutinase was not caused by a response to the cutinase protein, that (ii) cutinase was the most active esterase and by far the most active cutinase among the serine hydrolases tested, that (iii) the disease-preventing properties resided in esterase rather than cutinase activities, and that (iv) the residual esterase activity of proteinase $\mathrm{K}$, a typical serine protease, was not sufficient for plant protection.

Both cutinases and lipases are lipolytic esterases with hydrophobic substrate-binding sites accommodating fatty acid residues (Martinez et al. 1992, 1994). The nonspecific liver carboxylesterase shares part of these active site features even though it is not active as a lipase (Krisch 1971) nor, as shown in this study, as a cutinase. The nonspecific esterase contains two hydrophobic substrate-binding pockets of different sizes (Toone et al. 1990; Provencher and Jones 1994) and hydrolyzes fatty acid esters with relatively long alkyl chains (Krisch 1971). This broad substrate specificity of carboxylesterase was sufficient to protect bean leaves from disease. In contrast, the residual esterase activity of proteinase $\mathrm{K}$ had no impact on disease development. Although the active site of proteinase $\mathrm{K}$ contains hydrophobic regions that accommodate peptides as specific substrates (Wolf et al. 1991), these subsites are not sufficient for binding esters with long chain fatty acids. Therefore, we conclude that a lipolytic esterase activity toward fatty acid esters is responsible for the plant-protective activity.

The development of necrotic tissue at inoculation sites protected by cutinase prompted us to investigate the induction of $\mathrm{PR}$ proteins in response to the enzyme. Tissue necrosis is typical of HRs (Goodman and Novacky 1994; HammondKosack and Jones 1996) and is known to be accompanied by 
PR-protein synthesis (Dixon et al. 1994; Goodman and Novacky 1994; Hammond-Kosack and Jones 1996; Knogge 1996; Ryals et al. 1996). In bean tissue, the synthesis of the PR proteins evaluated in this study was shown to be induced during pathogenesis, in association with HRs, after exposure to nonspecific elicitors including salicylic acid derivatives and in response to wounding (Mahé et al. 1992, 1993; Meier et al. 1993; Dann et al. 1996; Milosevic and Slusarenko 1996; Tepper et al. 1989; Vögeli et al. 1988). The induction of PRprotein gene expression in the response of bean leaves to cutinase did not follow this established pattern: (i) cutinase displayed no pronounced elicitor activity when applied alone; (ii) high levels of PR-protein gene expression were only apparent during the undisturbed development of web blight symptoms; and (iii) protection of bean leaves by cutinase did not accelerate higher PR-protein gene expression during the initial phase of host-pathogen interaction and did not elevate gene expression during a later stage of leaf protection.

The results obtained for the induction of PR-protein genes supported our additional results. The pattern of gene expression followed closely the lack of autofluorescence of leaf tissue exposed to cutinase alone, the expanded, yet diffuse, autofluorescence of fully diseased tissue, and the sharply restricted areas of autofluorescence in the presence of both the pathogen and cutinase. The lack of any effect on disease development after wounding of bean leaves despite strong autofluorescense responses of wounded surfaces in the absence of the pathogen and the lack of evidence for cutinase-mediated permeability changes of the cuticle allowing an earlier induction of PR-protein synthesis by pathogen-derived elicitors strengthens our conclusion that the disease-preventing activity of cutinase is not explained by a modulation of typical PR-protein gene expression.

Our finding that the disease-preventing activity of the esterases employed in a comparative study was not dependent on their cutinolytic activities makes it unlikely that cutin monomers released during cutinase action were responsible for the described activity, as suggested recently by Schweizer et al. (1995, 1996a, 1996b). In fact, cutin hydrolysate employed at a concentration sufficient for inducing cutinase production in V. inaequalis (Köller et al. 1991) had no impact on the development of web blight on bean leaves (D. M. Parker and W. Köller, unpublished results). Furthermore, recent results have indicated that levels of cutin monomers sufficient for expression of monomer-induced cutinase might not be reached during cuticle penetration by fungal pathogens (Fan and Köller 1998; Yao and Köller 1995; Köller et al. 1995; Köller and Yao 1996).

In conclusion, the protective activity of lipolytic esterases described in this study might be caused by the release of yet unknown signals inducing genes different from typical PRprotein genes, by the enzymatic interference with crucial steps in host-pathogen interaction, or by a direct effect of esterases on the pathogen. All of these options are under current investigation. Respective results will be needed to further clarify the biological role of the effects described in this study.

\section{MATERIALS AND METHODS}

\section{Fungal cultures and materials.}

Rhizoctonia solani Kühn AG-1 (Thanetophorus cucumeris) was obtained from the American Type Culture Collection,
Rockville, MD (isolate number 42128). The esterase inhibitor $O$-methyl- $O$-butyl- $O$-(3,5,6-trichloro-2-pyridyl) phosphate was obtained from Bayer AG, Leverkusen, Germany. Radioactive grapefruit cutin was prepared as described elsewhere (Köller et al. 1982; Köller and Parker 1989). $\left[{ }^{14} \mathrm{C}(\mathrm{U})\right]$ amino acid mixture (2.1 GBq per matom carbon), $\left[\alpha^{32} \mathrm{P}\right] \mathrm{dCTP}$, and Protosol were obtained from NEN Life Science Products, Boston, MA. Potato dextrose agar (PDA) was acquired from Difco Laboratory, Detroit, MI. Carborundum was purchased from Universal Photonics, Inc., Hicksville, NY. Cutinase from $V$. inaequalis was purified as described elsewhere (Köller and Parker 1989). Cutinase from $F$. solani f. sp. pisi was a generous gift from P. E. Kolattukudy, the Ohio State University, Columbus, OH. Lipases PS 30 and AK were generously provided by Amano Enzyme U.S.A. Co., Troy, VA. Restriction enzymes were purchased from Promega Corp., Madison, WI. Hybond $\mathrm{N}^{+}$membranes for nucleic acid hybridization were purchased from Amersham, Arlington, IL. RNA size markers were purchased from Ambion, Inc., Austin, TX. All other chemicals were obtained from Sigma Chemical Co., St. Louis, MO.

The bean cDNAs pPAL1 for phenylalanine ammonia lyase (Edwards et al. 1985), pCHI1 for chalcone isomerase (Mehdy and Lamb 1987), pCHT12.2 for chitinase (Hedrick et al. 1988), and cPvME1 for malic enzyme (previously designated cinnamyl alcohol dehydrogenase) (Walter et al. 1988, 1994), were obtained from C. J. Lamb, Salk Institute, San Diego, CA.

\section{Serine hydrolases and enzyme assays.}

Cutinase from $V$. inaequalis was added in assays at a concentration of $10 \mu \mathrm{g} \mathrm{ml}^{-1}$. In the final purification step, cutinase from V. inaequalis was eluted in 60\% isopropanol (Köller and Parker 1989). Therefore, all assay solutions were adjusted to a final isopropanol concentration that never exceeded $3 \%$. Pathogenicity of $R$. solani (AG-1) was not impaired at this concentration of isopropanol. PS 30 and AK lipase, and proteinase $\mathrm{K}$ (3.4.21.64) were dissolved in $0.2 \%$ Tween 20 and centrifuged at $2,000 \times g$ for $10 \mathrm{~min}$. Porcine liver esterase (3.1.1.1, provided as a suspension in $3.2 \mathrm{M}$ ammonium sulfate) was dialyzed overnight in 1 liter of water. The dialyzed material was diluted in the same Tween 20 isopropanol mixture as the other enzymes.

Enzyme assays were performed as described elsewhere (Köller and Parker 1989). In brief, esterase activity was determined spectrophotometrically with PNB as the model substrate. This activity is designated PNBase activity. Cutinase activity was determined with tritiated grapefruit cutin. Assays of cutinase activity in 2-( $N$-morpholino)ethanesulfonic acid (MES) ( $\mathrm{pH}$ 6.5) were conducted twice with esterase equivalents of 5 and 50 nkat PNBase activities tested. Cutinase activity is expressed as cutinase units $(\mathrm{cu}=\mathrm{Bq}$ released from labeled cutin per minute). Protein concentrations were determined with the BCA Protein Assay Reagent (Pierce, Rockford, IL), with bovine serum albumin (BSA) as standard.

\section{Infection of bean leaves.}

A detached leaf assay according to the protocol of Galindo et al. (1982) was used to evaluate the protective activity of cutinase. Phaseolus vulgaris L. (cultivar Bush Blue Lake \#47) was cultivated in a growth chamber at $25^{\circ} \mathrm{C}, 65 \%$ humidity, 
with a 12-h photoperiod. Bean seedlings were grown for 14 days before fully developed primary leaves were used in the experiments. Mycelial fragments were scraped from a 5-dayold $R$. solani (AG-1) PDA culture that had been flooded with water. The resulting mycelial suspension was used to scrape the mycelium from two additional plates. Three cultures guaranteed a volume of material that could be subsequently homogenized with a Potter-Elvehjem tissue grinder to give a final volume of $3 \mathrm{ml}$ in water. Enzymes were adjusted to either $10 \mu \mathrm{g} \mathrm{ml} \mathrm{m}^{-1}$ or $0.175 \mu \mathrm{kat} \mathrm{ml}^{-1}$ PNBase activity with a final Tween 20 concentration of $0.1 \%$. Excised leaves were supported on a plastic grid in a sealable plastic box $(30 \times 20 \times 8$ $\mathrm{cm})$ with their petioles submerged in water. Drops $(10 \mu \mathrm{l})$ of each treatment were pipetted onto 6 leaves with six inoculation sites per leaf. The boxes were sealed and incubated at $25^{\circ} \mathrm{C}$ for $48 \mathrm{~h}$.

In assays including the serine esterase inhibitor $O$-methyl$O$-butyl-O-(3,5,6-trichloro-2-pyridyl) phosphate (Köller et al. 1991), cutinase purified from $V$. inaequalis $\left(20 \mu \mathrm{g} \mathrm{ml}^{-1}\right.$ in $0.2 \%$ Tween 20) was incubated with the inhibitor $\left(8 \mu \mathrm{g} \mathrm{ml}^{-1}\right.$ and $80 \mu \mathrm{g} \mathrm{m}^{-1}$ ) for $2 \mathrm{~h}$ and then mixed with an equal volume of a suspension containing mycelial fragments of $R$. solani. The mixture was employed in excised bean leaf assays conducted as described above.

In the comparative studies, enzymes were included at equivalent PNBase activities or equivalent protein concentrations. Assays conducted on wounded leaves were performed as described above except that inoculation sites on primary leaves were gently rubbed with Carborundum. Results were recorded after $48 \mathrm{~h}$. Lesion diameters were measured with a caliper. Autofluorescence was visualized with Mineralight Lamp Model UVGL-58 (UVP, Inc., San Gabriel, CA), with a wavelength of $366 \mathrm{~nm}$.

For whole plant assays, primary leaves were drop inoculated with 6 drops per leaf. Plants were enclosed in clear plastic bags; bags were moistened inside with an atomizer; and bagged plants were placed in a growth chamber at $25^{\circ} \mathrm{C}$ with 12-h light periods.

\section{Impact of cutinase on cuticle permeability.}

Four bean leaves were used to study increased permeability of leaf surfaces to amino acids. Each primary leaf had four designated treatment areas that were randomly selected. These areas were delineated with a 1-cm-diameter, 6-mm-high, tygon ring sealed onto the leaf surface with Vaseline. Excised leaves with treatments of $0.1 \%$ Tween 20 and $10 \mu \mathrm{g} \mathrm{ml}{ }^{-1}$ cutinase in $0.1 \%$ Tween 20 were placed in a sealable plastic box and incubated at $25^{\circ} \mathrm{C}$ for $24 \mathrm{~h}$. After $24 \mathrm{~h}$, the solutions were removed and each area was washed three times with 300 $\mu \mathrm{l}$ of water. Carborundum was gently rubbed on one of the four defined areas. A $\left[{ }^{14} \mathrm{C}\right]$ amino acid mixture at $18.5 \mathrm{kBq}$ per location was pipetted onto the three treated locations. After 60 $\mathrm{min}$, isotope was removed. All locations were washed three times with $300 \mu \mathrm{l}$ of water. The amino acid mixture was pipetted onto the fourth location, immediately removed, and followed by the same washing steps.

The treated areas were excised and placed into a scintillation vial, and $400 \mu \mathrm{l}$ of water was added. After the leaf tissue was macerated with a glass rod, $1 \mathrm{ml}$ of Protosol was added to each vial. Vials were incubated at room temperature for 5 days. Scintillation fluid $(10 \mathrm{ml})$ was added to each vial and vials were vortexed to dissolve the tissue. Samples were counted in an LKB liquid scintillation counter (PharmaciaWallac Oy, Turku, Finland).

\section{Induction of $P R$ protein genes.}

Detached leaf assays were conducted with samples collected at 6 and $36 \mathrm{~h}$. Treated sites (six on each leaf with a total of 6 leaves per treatment) were excised with a cork borer (1$\mathrm{cm}$-diameter disks yielding a total of $1 \mathrm{~g}$ of leaf tissue), frozen, and stored at $-80^{\circ} \mathrm{C}$ until processed. Total RNA from leaf disks was isolated according to Napoli et al. (1990) and frozen at $-20^{\circ} \mathrm{C}$. Concentration of RNA was determined with a GeneQuant (Pharmacia Biotech, Rockport, MD). Total RNA was denatured in $10 \mu \mathrm{l}$ of formamide sample buffer $(50 \mathrm{mM}$ morpholinopropanesulfonic acid [MOPS], 50\% formamide, $2.2 \mathrm{M}$ formaldehyde) at $65^{\circ} \mathrm{C}$ for $2 \mathrm{~min}$. Ficoll-dye-EDTA (3 $\mu \mathrm{l} ; 0.1 \mathrm{M}$ EDTA, $0.3 \%$ ficoll, trace bromophenol blue and xylene cyanol) and $1 \mathrm{ml}$ of ethidium bromide $\left(10 \mathrm{mg} \mathrm{ml}^{-1}\right)$ was added to each sample and the samples were electrophoresed in a $1.2 \%$ agarose gel containing $3.2 \%$ formaldehyde in $1 \times$ MOPS (Sambrook et al. 1989). RNA markers were employed to confirm the size of hybridizing mRNAs. Gels were blotted onto Hybond $\mathrm{N}^{+}$membrane in $20 \times \mathrm{SSC}(1 \times \mathrm{SSC}$ is $0.15 \mathrm{M} \mathrm{NaCl}, 0.015 \mathrm{M}$ sodium citrate). Membranes were heated at $80^{\circ} \mathrm{C}$ for $2 \mathrm{~h}$ (Sambrook et al. 1989; and manufacturer's recommendations).

All prehybridizations $(20 \mathrm{ml})$ and hybridizations $(10 \mathrm{ml})$ were performed at $60^{\circ} \mathrm{C}$ overnight in a solution of $1 \% \mathrm{BSA}, 1$ mM EDTA, 0.5 M sodium phosphate $\mathrm{pH} 7.2$, and 7\% sodium dodecyl sulfate (SDS) (Church and Gilbert 1984). Radioactive probes were randomly labeled with the Prime-a-Gene Labeling System (Promega). Membranes were washed at $60^{\circ} \mathrm{C}$ for $10 \mathrm{~min}$ in $100 \mathrm{ml} 0.5 \%$ BSA, $1 \mathrm{mM}$ EDTA, $40 \mathrm{mM}$ sodium phosphate $\mathrm{pH} 7.2$ and 5\% SDS followed by two $100 \mathrm{ml}$ washes at $60^{\circ} \mathrm{C}$ for $10 \mathrm{~min}$ each in $1 \mathrm{mM}$ EDTA, $40 \mathrm{mM}$ sodium phosphate $\mathrm{pH} 7.2$ and 1\% SDS (Church and Gilbert 1984). All membranes were exposed to Fuji film (Fuji Photo Film Co., LTD., Tokyo) at $-80^{\circ} \mathrm{C}$ for different periods according to the strength of hybridization signals.

\section{ACKNOWLEDGMENTS}

We wish to thank Amano Enzyme U.S.A. Co. for the generous gift of lipases PS 30 and AK, Asgrow Seed Co. for the gift of Bush Blue Lake bean seeds, Bayer AG for $O$-methyl- $O$-butyl- $O$-(3,5,6-trichloro-2pyridyl) phosphate, P. E. Kolattukudy for cutinase, and C. J. Lamb from the Salk Institute for providing cDNAs of PR proteins.

\section{LITERATURE CITED}

Baker, C. J., McCormick, S. L., and Bateman, D. F. 1982. Effects of purified cutin esterase upon the permeability and mechanical strength of cutin membranes. Phytopathology 72:420-423.

Bergey, D. R., Howe, G. A., and Ryan, C. A. 1996. Polypeptide signaling for plant defensive genes exhibits analogies to defense signaling in animals. Proc. Natl. Acad. Sci. USA 93:12053-12058.

Boller, T. 1995. Chemoperception of microbial signals in plant cells. Annu. Rev. Plant Physiol. Plant Mol. Biol. 46:189-214.

Brederode, F. T., Linthorst, H. J. M., and Bol, J. F. 1991. Differential induction of acquired resistance and $\mathrm{PR}$ gene expression in tobacco by virus, ethephon treatment, UV light and wounding. Plant Mol. Biol. 17:1117-1125.

Church, G. M., and Gilbert, W. 1984. Genomic sequencing. Proc. Natl. Acad. Sci. USA 81:1991-1995. 
Creelman, R. A., and Mullet, J. E. 1995. Jasmonic acid distribution and action in plants: Regulation during development and response to biotic and abiotic stress. Proc. Natl. Acad. Sci. USA 92:4114-4119.

Crowhurst, R. N., Binnie, S. J., Bowen, J. K., Hawthorne, B. T., Plummer, K. M., Rees-George, J., Rikkerink, E. H. A., and Templeton, M. D. 1997. Effect of disruption of a cutinase gene (cutA) on virulence and tissue specificity of Fusarium solani f. sp. cucurbitae race 2 toward Cucurbita maxima and C. moschata. Mol. Plant-Microbe Interact. 10: 355-368.

Dann, E. K., Meuwly, P., Métraux, J.-P., and Deverall, B. J. 1996. The effect of pathogen inoculation or chemical treatment on activities of chitinase and $\beta$-1,3-glucanase and accumulation of salicylic acid in leaves of green bean, Phaseolus vulgaris L. Physiol. Mol. Plant Pathol. 49:307-319.

Deising, H., Nicholson, R. L., Haug, M., Howard, R. J., and Mendgen, K. 1992. Adhesion pad formation and the involvement of cutinase and asterase in the attachment of uredospores to the host cuticle. Plant Cell 4:1101-1111.

Dillard, H. R. 1987. Characterization of isolates of Rhizoctonia solani from lima beans grown in New York State. Phytopathology 77:748751.

Dixon, R. A., Harrison, M. J., and Lamb, C. J. 1994. Early events in the activation of plant defense responses. Annu. Rev. Phytopathol. 32:479-501.

Dixon, R. A., and Paiva, N. L. 1995. Stress-induced phenylpropanoid metabolism. Plant Cell 7:1085-1097.

Edwards, K., Cramer, C. L., Bolwell, G. P., Dixon, R. A., Schuch, W. and Lamb, C. J. 1985. Rapid transient induction of phenylalanine ammonia-lyase mRNA in elicitor-treated bean cells. Proc. Natl. Acad. Sci. USA 82:6731-6735.

Fan, C.-F., and Köller, W. 1998. Diversity of cutinases from plant pathogenic fungi: Differential and sequential expression of cutinolytic esterases by Alternaria brassicicola. FEMS Microbiol. Lett. 158:33-38.

Farmer, E. E. 1994. Fatty acid signalling in plants and their associated microorganisms. Plant Mol. Biol. 26:1423-1437.

Francis, S. A., Dewey, F. M., and Gurr, S. J. 1996. The role of cutinase in germling development and infection by Erysiphe graminis f.sp. hordei. Physiol. Mol. Plant Pathol. 49:201-211.

Galindo, J. J., Abawi, G. S., and Thurston, H. D. 1982. Variability among isolates of Rhizoctonia solani associated with snap bean hypocotyls and soils in New York. Plant Dis. 66:390-394.

Gérard, H. C., Fett, W. F., Osman, S. F., and Moreau, R. A. 1993 Evaluation of cutinase activity of various industrial lipases. Biotechnol. Appl. Biochem. 17:181-189.

Gilbert, E. J., Cornish, A., and Jones, C. W. 1991. Purification and properties of extracellular lipase from Pseudomonas aeruginosa EF2. J. Gen. Microbiol. 137:2223-2230.

Goodman, R. N., and Novacky, A. J. 1994. The Hypersensitive Reaction in Plants to Pathogens: A Resistance Phenomenon. American Phytopathological Society, St. Paul, MN.

Hammond-Kosack, K. E., and Jones, J. D. G. 1996. Resistance genedependent plant defense responses. Plant Cell 8:1773-1791.

Hedrick, S. A., Bell, J. N., Boller, T., and Lamb, C. J. 1988. Chitinase cDNA cloning and mRNA induction by fungal elicitor, wounding, and infection. Plant Physiol. 86:182-186.

Knogge, W. 1996. Fungal infection of plants. Plant Cell 8:1711-1722.

Kolattukudy, P. E. 1985. Enzymatic penetration of the plant cuticle by fungal pathogens. Annu. Rev. Phytopathol. 23:223-250.

Kolattukudy, P. E. 1992. Plant-fungal communications that trigger genes for breakdown and reinforcement of host defensive barriers. Pages $65-$ 83 in: Molecular Signals in Plant-Microbe Communications. D. P. S. Verma, ed. CRC Press, Boca Raton, FL.

Kolattukudy, P. E., Li, D., Hwang, C., and Flaishman, M. A. 1995a. Host signals in fungal gene expression involved in penetration into the host. Can. J. Bot. 73: S1160-S1168.

Kolattukudy, P. E., Rogers, L. M., Li, D., Hwang, C.-S., and Flaishman, M. A. 1995b. Surface signaling in pathogenesis. Proc. Natl. Acad. Sci. USA 92:4080-4087.

Köller, W. 1991. The plant cuticle. Pages 219-246 in: The Fungal Spore and Disease Initiation in Plants and Animals. G. T. Cole and H. C. Hoch, eds. Plenum Press, New York.

Köller, W., Allan, C. R., and Kolattukudy, P. E. 1982. Role of cutinase and cell wall degrading enzymes in infection of Pisum sativum by Fusarium solani f. sp. pisi. Physiol. Plant Pathol. 20:47-60.
Köller, W., and Kolattukudy, P. E. 1982. Mechanism of action of cutinase: chemical modification of the catalytic triad characteristic for serine hydrolases. Biochemistry 21:3083-3090.

Köller W., and Parker, D. M. 1989. Purification and characterization of cutinase from Venturia inaequalis. Phytopathology 79:278-283.

Köller, W., Parker, D. M., and Becker, C. M. 1991. Role of cutinase in the penetration of apple leaves by Venturia inaequalis. Phytopathology $81: 1375-1379$.

Köller W., and Yao, C. 1996. Targets for plant protection-can cutinase be counted in? Pages 163-172 in: Modern Fungicides and Antifungal Compounds. H. Lyr, P. E. Russell, and H. D. Sisler, eds. Intercept, Andover, UK.

Köller, W., Yao, C., Trail, F., and Parker, D. M. 1995. Role of cutinase in the invasion of plants. Can. J. Bot. 73: S1109-S1118.

Krisch, K. 1971. Carboxylic ester hydrolases. Pages 43-69 in: The Enzymes, Vol. 5, 3rd. ed. P. D. Boyer, ed. Academic Press, New York.

Lange, J., Mohr, U., Wiemken, A., Boller, T., and Vögeli-Lange, R. 1996. Proteolytic processing of class IV chitinase in the compatible interaction of been roots with Fusarium solani. Plant Physiol. 111:1135-1144.

Lawton, M. A., and Lamb, C. J. 1987. Transcriptional activation of plant defense genes by fungal elicitor, wounding, and infection. Mol. Cell. Biol. 7:335-341.

Li, D., and Kolattukudy, P. E. 1995. Cloning and expression of cDNA encoding a protein that binds a palindromic promotor element essential for induction of fungal cutinase by plant cutin. J. Biol. Chem. 270:11753-11756.

Li, D., and Kolattukudy, P. E. 1997. Cloning of cutinase transcription factor 1, a transactivating protein containing Cys6Zn2 binuclear cluster DNA-binding motif. J. Biol. Chem. 272:12462-12467.

Longhi, S., Mannesse, M., Verheij, H. M., De Haas, G. H., Egmond, M., Knoops-Mouthuy, E., and Cambillau, C. 1997. Crystal structure of cutinase covalently inhibited by a triglyceride analogue. Protein Sci. 6:275-286.

Mahé, A., Grisvard, J., and Dron, M. 1992. Fungal- and plant-specific gene markers to follow the bean anthracnose infection process and normalize a bean chitinase mRNA induction. Mol. Plant-Microbe Interact. 5:242-248.

Mahé, A., Grisvard, J., and Dron, M. 1993. Two avirulent races of Colletotrichum lindemuthianum trigger different time courses of plant defense reactions in bean. Mol. Plant-Microbe Interact. 6:423-428.

Mannesse, M. L. M., Cox, R. C., Koops, B. C., Verheij, H. M., deHaas, G. H., Egmond, M. R., van der Hkjden, H. T. W. M., and de Vlieg, J. 1995. Cutinase from Fusarium solani pisi hydrolyzing triglyceride analogues. Effect of acyl chain length and position in the substrate molecule on activity and enantioselectivity. Biochemistry 34:64006407.

Martinez, C., de Gues, P., Lauwereys, M., Matthyssens, G., and Cambillau, C. 1992. Fusarium solani cutinase is a lipolytic enzyme with a catalytic serine accessible to solvent. Nature 356:615-618.

Martinez, C. Nicolas, A., van Tilbeurgh, H., Egloff, M.-P., Cudrey, C., Verger, R., and Cambillau, C. 1994. Cutinase, a lipolytic enzyme with a preformed oxyanion hole. Biochemistry 33:83-89.

Mehdy, M. C., and Lamb, C. J. 1987. Chalcone isomerase cDNA cloning and mRNA induction by fungal elicitor, wounding and infection. EMBO J. 6:1527-1533.

Mehta, R. A., Parsons, B. L., Mehta, A. M., Nakhasi, H. L., and Mattoo, A. K. 1991. Differential protein metabolism and gene expression in tomato fruit during wounding and stress. Plant Cell Physiol. 32:10571065 .

Meier, B. M., Shaw, N., and Slusarenko, A .J. 1993. Spatial and temporal accumulation of defense gene transcripts in bean (Phaseolus vulgaris) leaves in relation to bacteria-induced hypersensitive cell death. Mol. Plant-Microbe Interact. 6:453-466.

Milosevic, N., and Slusarenko, A. J. 1996. Active oxygen metabolism and lignification in the hypersensitive response in bean. Physiol. Mol. Plant Pathol. 49:143-158.

Muyolo, N. G., Lipps, P. E., and Schmitthenner, A. F. 1993. Reactions of dry bean, lima bean, and soybean cultivars to Rhizoctonia root and hypocotyl rot and web blight. Plant Dis. 77:234-238.

Napoli, C., Lemeius, C., and Jorgensen, R. 1990. Introduction of a chimeric chalcone synthase gene into petunia results in reversible cosuppression of homologous genes in trans. Plant Cell 2:279-289.

Nicholson, R. L., and Kunoh, H. 1995. Early interactions, adhesion, and 
establishment of the infection court by Erysiphe graminis. Can. J. Bot. 73:S609-S615.

Ohnishi, K., Toida, J., Nakazawa, H., and Sekiguchi, J. 1995. Genome structure and nucleotide sequence of a lipolytic enzyme gene of Aspergillus oryzae. FEMS Microbiol. Lett. 126:145-150.

Pascholati, S. F., Deising, H., Leite, B., Anderson, D., and Nicholson, R. L. 1993. Cutinase and non-specific esterase activities in the conidial mucilage of Colletotrichum graminicola. Physiol. Mol. Plant Pathol. 42:37-51.

Provencher, L., and Jones, J. B. 1994. A concluding specification of the dimensions of the active site model of pig liver esterase. J. Org. Chem. 59:2729-2732.

Ryals, J. A., Neuenschwander, U. H., Willits, M. G., Molina, A., Steiner, H.-Y., and Hunt, M. D. 1996. Systemic acquired resistance. Plant Cell 8:1809-1819.

Ryan, C. A. 1984. Systemic responses to wounding. Pages 307-320 in: Plant-Microbe Interactions: Molecular and Genetic Perspectives, Vol. 1. T. Kosuge and E. W. Nester, eds. Macmillan, New York.

Sambrook, J., Fritsch, E. F., and Maniatis, T. A. 1989. Molecular Cloning: A Laboratory Manual. 2nd ed. Cold Spring Harbor Laboratory, Cold Spring Harbor, NY.

Schaaf, J., Walter, M. H., and Hess, D. 1995. Primary metabolism in plant defense: Regulation of a bean malic enzyme gene promoter in transgenic tobacco by developmental and environmental cues. Plant Physiol. 108:949-960.

Schäfer, W. 1993. The role of cutinase in fungal infection. Trends Microbiol. 1:69-71.

Schäfer, W. 1994. Molecular mechanisms of fungal pathogenicity to plants. Annu. Rev. Phytopathol. 32:461-477.

Schwartz, H. F. 1991. Web blight. Page 27 in: Compendium of Bean Diseases. R. Hall, ed. American Phytopathological Society, St. Paul, MN.

Schweizer, P., Bindschedler, L., Meuwly, P., Mölders, W., Coquoz, J.-L., Buchala, A., and Métraux, J.-P. 1995. Approaches to identify genes for disease resistance in plants. Pages 225-235 in: Int. Congr. Pestic. Chem. - Options 2000, 8th. N. N. Ragsdale, P. C. Kearney, and J. R. Plimmer, eds. American Chemical Society, Washington, DC.

Schweizer, P., Felix, G., Buchala, A., Müller, C., and Métraux, J.-P. 1996a. Perception of free cutin monomers by plant cells. Plant J. 10: 331-341.

Schweizer, P., Jeanguenat, A., Whitacre, D., and Métraux, J.-P. 1996 b. Induction of resistance in barley against Erysiphe graminis f. sp. hordei by free cutin monomers. Physiol. Mol. Plant Pathol. 49:103-120.

Siezen, R. J., and Leunissen, J. A. M. 1997. Subtilases: The superfamily of subtilisin-like serine proteases. Protein Sci. 6:501-523.

Smith, C. G., Rodgers, M. W., Zimmerlin, A., Ferdinando, D., and Bolwell, G. P. 1994. Tissue and subcellular immunolocalisation of enzymes of lignin synthesis in differentiating and wounded hypocotyl tissue of French bean (Phaseolus vulgaris L.). Planta 192:155-164.

Stahl, D. J., Theuerkauf, A., Heitefuss, R., and Schäfer, W. 1994. Cutinase of Nectria haematococca (Fusarium solani f. sp. pisi) is not required for fungal virulence or organ specificity on pea. Mol. Plant-
Microbe Interact. 7:713-725.

Stockwell, V., and Hanchey, P. 1985. Effect of cuticle treatments on infection of Phaseolus vulgaris by Rhizoctonia solani. Phytopathol. Z. 114:6-12.

Stockwell, V., and Hanchey, P. 1987. Lignification of lesion borders in Rhizoctonia- infected bean hypocotyls. Phytopathology 77:589-593.

Sweigard, J. A., Chumley, F. G., and Valent, B. 1992. Disruption of a Magnaporthe grisea cutinase gene. Mol. Gen. Genet. 232:183-190.

Tepper, C. S., Albert, F. G., and Anderson, A. J. 1989. Differential mRNA accumulation in three cultivars of bean in response to elicitors from Colletotrichum lindemuthianum. Physiol. Mol. Plant Pathol. 34: 85-98.

Toone, E. J., Werth, M. J., and Jones, J .B. 1990. Active-site model for interpreting and predicting the specificity of pig liver esterase. J. Am. Chem. Soc. 112:4946-4952.

Trail, F., and Köller, W. 1990. Diversity of cutinases from plant pathogenic fungi: evidence for a relationship between enzyme properties and tissue specificity. Physiol. Mol. Plant Pathol. 36:495-508.

van der Vlugt-Bergmans, C. J. B., Wagemakers, C. A. M., and van Kan J. A. L. 1997. Cloning and expression of the cutinase A gene of Botrytis cinerea. Mol. Plant-Microbe Interact. 10:21-29.

van Kan, J. A. L., van't Klooster, J. W., Wagemakers, C. A. M., Dees, D. C. T., and van der Vlugt-Bergmans, C. J. B. 1997. Cutinase A of Botrytis cinerea is expressed, but not essential, during penetration of gerbera and tomato. Mol. Plant-Microbe Interact. 10:30-38.

Vögeli, U., Meins, Jr., F., and Boller, T. 1988. Co-ordinated regulation of chitinase and $\beta$-1,3-glucanase in bean leaves. Planta 174:364-372.

Walter, M. H., Grima-Pettenati, J., and Feuillet, C. 1994. Characterization of a bean (Phaseolus vulgaris L.) malic-enzyme gene. Eur. J. Biochem. 224:999-1009.

Walter, M. H., Grima-Pettenati, J., Grand, C., Boudet, A. M., and Lamb, C. J. 1988. Cinnamyl-alcohol dehydrogenase, a molecular marker specific for lignin synthesis: cDNA cloning and mRNA induction by fungal elicitor. Proc. Natl. Acad. Sci. USA 85:5546-5550.

Whittaker, R. G., Manthey, M. K., Le Brocque, D. S., and Hayes, P. J. 1994. A microtiter plate assay for the characterization of serine proteases by their esterase activity. Anal. Biochem. 220:238-243.

Wolf, W. M., Bajorath, J., Mueller, A., Raghunathan, S., Singh, T. P., Hinrichs, W., and Saenger, W. 1991. Inhibition of proteinase K by methoxysuccinyl-ala-ala-pro-ala- chloromethyl ketone an x-ray study at 2.2 A resolution. J. Biol. Chem. 266:17695-17699.

Woloshuk, C. P., and Kolattukudy, P. E. 1986. Mechanisms by which contact with plant cuticle triggers cutinase gene expression in the spores of Fusarium solani f. sp. pisi. Proc. Natl. Acad. Sci. USA 83: 1704-1708.

Yang, X. B., Berggren, G. T., and Snow, J. P. 1990. Seedling infection of soybean by isolates of Rhizoctonia solani AG-1, causal agent of aerial blight and web blight of soybean. Plant Dis. 74:485-488.

Yao, C., and Köller, W. 1995. Diversity of cutinases from plant pathogenic fungi: Different cutinases are expressed during saprophytic and pathogenic stages of Alternaria brassicicola. Mol. Plant-Microbe Interact. 8:122-130. 